\title{
Admixture promotes genetic variation in bottlenecked moose populations in eastern Poland
}

\author{
Magdalena Świsłocka • Magdalena Czajkowska • \\ Norbert Duda $\cdot$ Miroslaw Ratkiewicz
}

Received: 24 July 2014 / Accepted: 13 February 2015 /Published online: 28 February 2015

(C) The Author(s) 2015. This article is published with open access at Springerlink.com

\begin{abstract}
Human activity has led to severe bottlenecks in many wildlife species in the recent past. This usually increases the strength of genetic drift, leading to loss of genetic variation. Gene flow may however counteract the genetic consequences of small population size. Using 11 of 38 tested microsatellite loci and five moose populations in eastern Poland, we investigated the effects of two phenomena: bottlenecks that occurred in the nineteenth century and the first half of twentieth century, and admixture after moose populations expanded demographically and spatially in eastern Poland after the Second World War. The statistical tests indicated a recent bottleneck in all the studied samples with respect to $H_{E}$ and low Garza-Williamson index values. The Biebrza population, which consists of autochthonous moose representing a branch of the Central Europe mitochondrial DNA (mtDNA) clade and immigrants belonging to the Ural clade, is one of the most variable populations of this species. AMOVA, PCA, and STRUCTURE analyses all revealed significant population structuring, with most probable existence of $K=2$ genetically distinct clusters that exhibited a relatively high level of admixture. Analysis of recent dispersal rates demonstrated that population from the Biebrza Valley may supply individuals to the other four studied moose populations. We also found female-biased sex ratio in nonharvested moose populations inhabiting eastern Poland.
\end{abstract}

Keywords Admixture $\cdot$ Bottleneck $\cdot$ Cross-species amplification $\cdot$ Microsatellites $\cdot$ Relict population $\cdot$ Ungulates

Communicated by: Allan McDevitt

Electronic supplementary material The online version of this article (doi:10.1007/s13364-015-0221-5) contains supplementary material, which is available to authorized users.

M. Świsłocka $(\varangle) \cdot$ M. Czajkowska $\cdot$ N. Duda $\cdot$ M. Ratkiewicz Institute of Biology, University of Białystok, Świerkowa 20B, 15-950 Białystok, Poland

e-mail: magdaswi@uwb.edu.pl

\section{Introduction}

Knowledge of genetic structure is an essential element of wildlife management and conservation (Haanes et al. 2011). The population genetics and evolutionary history of ungulates, a group of ecologically, socially, and economically important species, have received much attention (e.g., Hundertmark et al. 2002; Świsłocka et al. 2013; Queiros et al. 2014). The moose (Alces alces) is the largest species among the Cervidae and an important game animal. In European boreal forests, it plays a keystone ecological role; it can alter ecosystem structure and functioning (Graham et al. 2010; Czernik et al. 2013).

The maximum range of moose in Central Europe, which took shape in the Boreal period (9000-7000 BP), rapidly shrank during the Middle Ages; moose vanished from large parts of western and southern Central Europe (Schmölcke and Zachos 2005; Raczyński 2006). Increasing habitat fragmentation, excessive hunting, and changes in climate and vegetation are undoubtedly the most important factors in local disappearance of moose and declining population density since the 1600s (Mysterud et al. 2002; Raczyński 2006). By the mid1800 s, only a few isolated moose populations survived in Central Europe (Brincken 1826). Thus, one should expect to find evidence of genetic drift due to bottleneck events in moose populations. Some reports suggest that moose had died out in Poland by 1830 (Schmölcke and Zachos 2005), but it is very likely that up to the twentieth century, it did survive in a few scattered areas of Poland (Dzięciołowski and Pielowski 1993). One such area was the Biebrza marshes in northeastern Poland (Brincken 1826; Gębczyńska and Raczyński 2004). After the Second World War, the whole moose population in Poland was again on the verge of total extinction. Between 10 and 20 individuals survived this period in the Biebrza River Valley; they formed the founding group for the present-day moose population in this region of Poland (Dzięciołowski and 
Pielowski 1993). The unique relict character of the Biebrza moose population was recently confirmed by molecular analyses of the mitochondrial DNA control region (Świsłocka et al. 2008; Niedziałkowska et al. 2014) and cytochrome $b$ gene, and also Y-chromosome markers-YCATS (Ychromosome conserved anchor tagged sequences) and the SRY gene (Świsłocka et al. 2013).

On one hand, the effects of population bottlenecks are directly related to the increase of stochastic events associated with small population size, which in most cases leads to loss of genetic diversity (Bouzat 2010; Peery et al. 2012). Loss of genetic diversity is commonly accompanied by decreased fitness at both individual and population levels (Grueber et al. 2008; Hedrick and Fredrickson 2010). On the other hand, increased gene flow opposes genetic drift and enriches genetic variation (Alleaume-Benharira et al. 2006; Biebach and Keller 2012). When genetically differing populations merge, the level of genetic variation can increase as a result of isolate breaking (Hartl and Clark 1997). Thus, the following questions arise - if the Biebrza moose population gained a significant admixture from the spatial and demographic expansion of moose populations from the former Soviet Union soon after the Second World War, would this prevent detection of a genetic bottleneck? What is the contemporary dispersal level and admixture among this population and other moose populations in eastern Poland?

Despite the biological and socioeconomic importance of moose, only a few studies have used microsatellite loci to examine population genetic structure and diversity for European moose populations (Charlier et al. 2008; Haanes et al. 2011; Kangas et al. 2013). Microsatellites have been considered the markers of choice because they are highly polymorphic, codominant, and amenable to PCR technique (e.g., Kohler et al. 2011). Another potentially crucial advantage of many microsatellites is that closely related species appear to have conserved their microsatellites together with their flanking sequences, allowing primer sets to be used across species (e.g., Talbot et al. 1996). Microsatellite loci are also useful for identifying individuals and their sex by noninvasive sampling; that information is essential in conservation genetics and in research on the behavioral ecology of wild animals (Taberlet and Luikart 1999; Arandjelovic et al. 2011).

We tested 38 commonly used wild ungulate microsatellite markers to study genetic material collected noninvasively from five moose populations in eastern Poland, including a relict Biebrza Valley population. The objectives of this study were (i) to test, in moose, amplification of 38 pairs of abovementioned microsatellite primers and to design a suite of microsatellites that was large enough to reliably measure genetic variability and the $S R Y$ gene for sex identification, (ii) to determine the levels of genetic variation at nuclear microsatellite loci in the relict moose population from the Biebrza
Valley and in four neighboring populations from eastern Poland, and (iii) to test for signs of recent bottlenecks and admixture in populations under study.

\section{Material and methods}

Sampling and DNA extraction

A total of 231 moose samples were collected in 2007 and 2011 from five geographical locations in eastern Poland (Fig. 1). Eighty-two samples were taken from a relict moose population in the Biebrza Valley ( $\left.53^{\circ} 24^{\prime} 25^{\prime \prime} \mathrm{N}, 22^{\circ} 47^{\prime} 43^{\prime \prime} \mathrm{E}\right), 37$ samples from the Augustów Forest (53 $53^{\circ} 46^{\prime \prime} \mathrm{N}, 23^{\circ} 17^{\prime} 23^{\prime \prime}$ E), 46 from the Knyszyn Forest ( $\left.53^{\circ} 10^{\prime} 35^{\prime \prime} \mathrm{N}, 23^{\circ} 48^{\prime} 47^{\prime \prime} \mathrm{E}\right)$ and also from the Polesie National Park $\left(51^{\circ} 23^{\prime} 37^{\prime \prime} \mathrm{N}, 23^{\circ}\right.$ $11^{\prime} 41^{\prime \prime}$ E), and 20 samples from the Srokowo State Forest population $\left(54^{\circ} 12^{\prime} 49^{\prime \prime} \mathrm{N}, 21^{\circ} 31^{\prime} 15^{\prime \prime} \mathrm{E}\right.$; Fig. 1). The Biebrza Valley is Central Europe's largest natural wetlands area $(59,223 \mathrm{ha})$, which since 1993 is a protected area, Biebrza National Park. Because hunting moose has been banned in Poland since 2001, the 84 samples of muscle and skin were taken from animals killed in road accidents, found dead after winter or poached. Additionally, 147 stool samples (from five populations) were collected in winter. Samples were stored at $-20{ }^{\circ} \mathrm{C}$ pending DNA extraction, which used the DNeasy Blood and Tissue Kit or, for stool samples, the QIAamp DNA Stool Mini Kit (Qiagen, Germany).

\section{Genotyping}

First, we tested 38 microsatellite loci that have been successfully amplified in other hoofed species: Bos taurus-BM1258 (Hediger et al. 1991), BovirBP, MM12 (Moore et al. 1992), MAF46 (Swarbrick et al. 1992), INRA003 (Vaiman et al. 1992), INRA35 (Steffen et al. 1993), TGLA53 (Barendse et al. 1994), BL42, BM1225, BM2830, BM4513, BM861, BM888, BMC1009, IOBT965 (Bishop et al. 1994), CSSM003 (Moore et al. 1994), INRA124 (Vaiman et al. 1994), Haut14 (Thieven et al. 1995), INRA189 (Kappes et al. 1997), UMN2404 (Liu et al. 2002), and UMN2001 (Liu et al. 2003); Cervus elaphus-CelJP15 (Pemberton et al. 1995); Odocoileus virginianus - Cer14 (DeWoody et al. 1995); Ovis aries-MAF70 (Buchanan and Crawford 1992), OarFCB193, OarFCB304 (Buchanan and Crawford 1993), OarFCB20 (Buchanan et al. 1994), McM58, and McM130 (Hulme et al. 1994); and Rangifer tarandus-RT5, RT9, RT23, RT24, RT27, RT30 (Wilson et al. 1997), NVHR T01, NVHRT21, and NVHRT24 (Røed and Midthjell 1998) (Table 5S1 and Table 6S2). Markers were selected on the basis of their previous cross-species utility, size range, and ability to co-amplify in multiplex PCRs. The initial thermocycling programs for all tested microsatellite loci were generally the 
Fig. 1 Study area and moose sampling in eastern Poland. Circles denoted areas where moose samples (Alces alces) were collected. Values of recent migration rates between the Biebrza moose population and other moose populations in eastern Poland obtained using BAYESASS v.1.3 are given above arrows. BIE a relict moose population in the Biebrza Valley, $A U F$ the Augustów Forest population, $K N F$ the Knyszyn Forest population, PNP the Polesie National Park population, $S R F$ the Srokowo State Forest population, $B Y$ Belarus, LT Lithuania, RUS Russia, $U A$ Ukraine

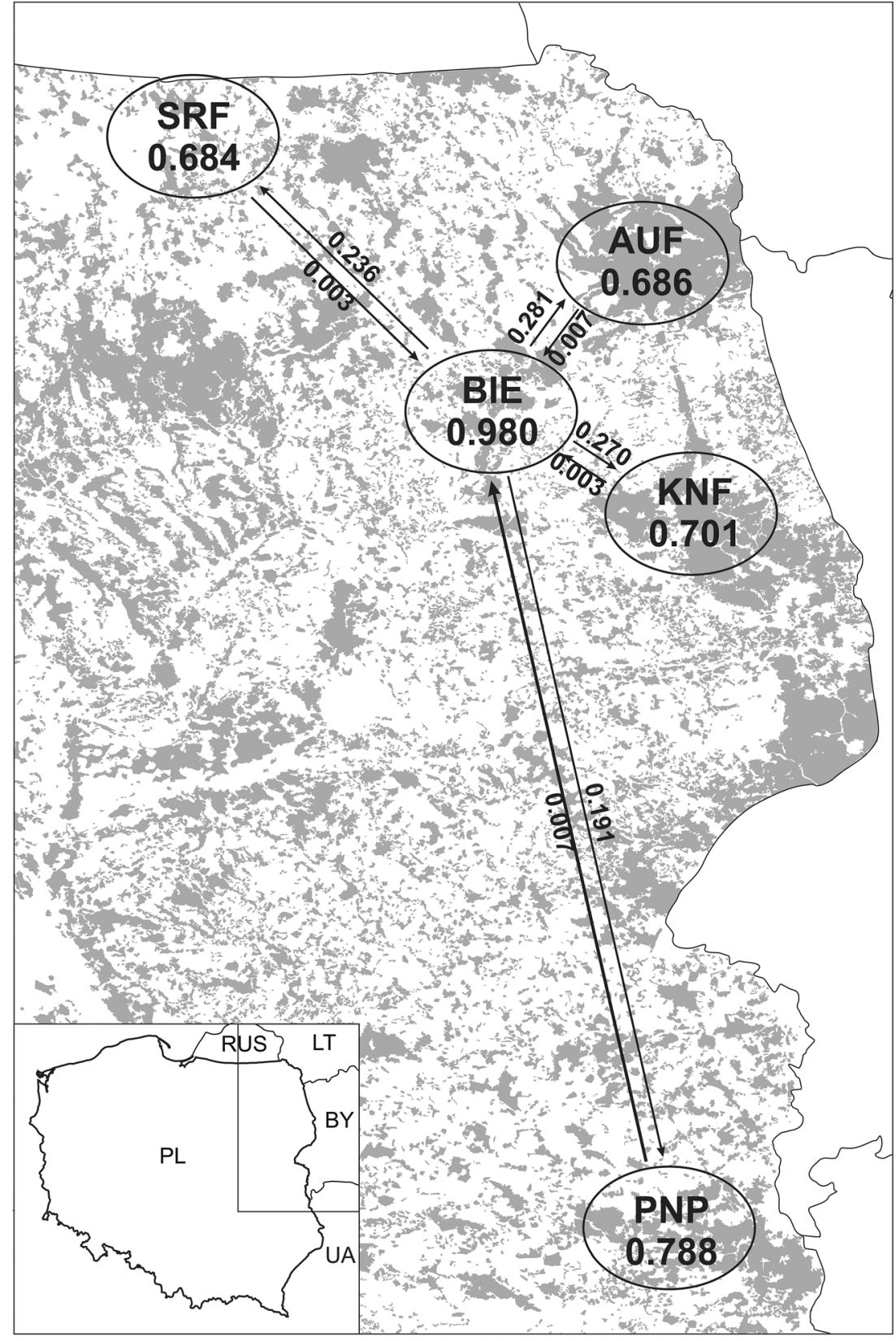

same, differing only in annealing temperature $(\mathrm{Ta}): 45.5^{\circ} \mathrm{C}$ for locus CelJP15, $48.8^{\circ} \mathrm{C}$ for INRA35 and MM12, $50{ }^{\circ} \mathrm{C}$ for INRA003, $51.5^{\circ} \mathrm{C}$ for IOBT965, $54{ }^{\circ} \mathrm{C}$ for RT9 and RT27, $55^{\circ} \mathrm{C}$ for BM1225, BM2830, and NVRT24, and $57^{\circ} \mathrm{C}$ for the other analyzed microsatellite loci. Because many samples were from moose of unknown sex, we also amplified an 333-bp fragment of the SRY gene (Świsłocka et al. 2013) together with microsatellite loci in set 2 in order to genetically identify the sex of the studied animals.

Finally, we chose 11 microsatellite loci that gave satisfactory amplification results, exhibited consistent genotypes, and were characterized by the highest number of alleles. These 11 loci were amplified into two multiplex sets avoiding allele overlap between loci labeled with the same dye (Table 1). The two sets of 11 primers contained four bovine, three ovine, one white-tailed deer, and three reindeer primers (Table 1 and Table 5S1). Each forward primer was end-labeled with one of the following fluorescent dyes, VIC, FAM, NED, or PET (Life Technologies, Inc.), and optimized for resolution on an ABI 3130 Genetic Analyzer (Table 1). Despite the variability of expected product lengths and heterozygosity, the optimal conditions for multiplex PCRs were similar across all $11 \mathrm{mi}$ crosatellite loci. Multiplex PCRs were performed with 25 ng genomic DNA, 1.7 $\mu \mathrm{L}$ Qiagen multiplex PCR Master Mix $(1 \times), 0.3 \mu \mathrm{L}$ mix of primers, and $1 \mu \mathrm{L}$ RNase-free water in a $5-\mu \mathrm{L}$ reaction volume. Thermocycling parameters after 
Table 1 Summary characteristics of 11 microsatellite loci scored in five moose populations from eastern Poland

\begin{tabular}{|c|c|c|c|c|c|c|c|c|c|}
\hline Set & Dye & Number of alleles & Null & PIC & $A_{\mathrm{R}}$ & $H_{\mathrm{O}}$ & $H_{\mathrm{E}}$ & $F_{\text {IS }}$ & HWE \\
\hline \multicolumn{10}{|c|}{ North-Eastern Poland } \\
\hline \multicolumn{10}{|l|}{ Set 1} \\
\hline BM1258 & NED & 7 & +0.018 & 0.709 & 5.238 & 0.723 & 0.751 & 0.038 & ns \\
\hline OarFCB193 & FAM & 10 & +0.049 & 0.671 & 5.321 & 0.649 & 0.723 & $0.103^{*}$ & $\mathrm{~ns}$ \\
\hline RT5 & FAM & 12 & +0.064 & 0.771 & 7.661 & 0.703 & 0.799 & $0.121^{*}$ & $\mathrm{~ns}$ \\
\hline NVHRT21 & VIC & 8 & +0.049 & 0.730 & 6.021 & 0.695 & 0.767 & 0.093 & $*$ \\
\hline RT30 & NED & 9 & +0.070 & 0.788 & 7.159 & 0.707 & 0.814 & $0.131^{*}$ & $\mathrm{~ns}$ \\
\hline BM1225 & FAM & 11 & +0.068 & 0.857 & 8.508 & 0.759 & 0.874 & $0.132 *$ & ns \\
\hline \multicolumn{10}{|l|}{ Set 2} \\
\hline MAF46 & NED & 9 & -0.004 & 0.729 & 5.608 & 0.770 & 0.768 & -0.002 & ns \\
\hline BM4513 & VIC & 13 & +0.102 & 0.766 & 7.380 & 0.648 & 0.793 & 0.184* & $* *$ \\
\hline MAF70 & FAM & 11 & +0.043 & 0.656 & 6.919 & 0.641 & 0.688 & 0.068 & $\mathrm{~ns}$ \\
\hline McM58 & PET & 14 & +0.126 & 0.735 & 7.148 & 0.594 & 0.765 & $0.224 *$ & $* * *$ \\
\hline Cer14 & FAM & 9 & +0.064 & 0.834 & 7.446 & 0.749 & 0.854 & $0.124^{*}$ & $* * *$ \\
\hline SRY & VIC & 1 & - & - & - & 0.000 & 0.000 & - & - \\
\hline
\end{tabular}

Data are based on 202 individuals

Null null alleles frequency, PIC mean polymorphic information content, $A_{R}$ allelic richness, $H_{O}$ observed heterozygosity, $H_{E}$ expected heterozygosity, $F_{I S}$ inbreeding coefficient $(p=0.0045)$, HWE significance level of deviation from expected Hardy-Weinberg genotype frequencies, $n s$ nonsignificant deviation from $H W E$

${ }^{*} p<0.0045 ; * * p<0.01 ; * * * p<0.001$

denaturation at $95^{\circ} \mathrm{C}$ for 15 min were 35 cycles with denaturation at $94{ }^{\circ} \mathrm{C}$ for $30 \mathrm{~s}$, annealing at $57^{\circ} \mathrm{C}$ for $90 \mathrm{~s}$, extension at $72{ }^{\circ} \mathrm{C}$ for $60 \mathrm{~s}$, and final extension at $60{ }^{\circ} \mathrm{C}$ for $30 \mathrm{~min}$. Multiplex PCRs were performed in a GeneAmp PCR System 9600 thermal cycler (Applied Biosystems). The multiplex PCR products were then separated by size by capillary electrophoresis (3130 Genetic Analyzer, Applied Biosystems) using the GeneScan 500 LIZ standard, and finally, the electromorphs were genotyped with GeneMapper 4.0 (Applied Biosystems). To ensure consistency of genotyping, we repeated the amplifications of all chosen 11 microsatellite loci for $10 \%$ of the samples, blind, and compared the results with those obtained from the first amplification.

\section{Statistical analyses}

We used CERVUS 3.0.3 (Kalinowski et al. 2007) to carry out identity analysis of the microsatellite data set $(N=231$ animals genotyped at up to 11 polymorphic microsatellite loci), counting the number of pairs of genotypes that were identical at all loci. This was required because we analyzed 147 stool samples collected from an unknown number of moose. The 231 multi-locus (e.g., 11) genotypes were assigned to 202 different individuals. Of the 231 genotypes detected, 185 were sampled once, six were sampled twice, ten were obtained three times, and one was sampled four times.

The data for 11 microsatellite loci were first checked with FSTAT v.2.9.3.2 (Goudet 1995) to test genotypic linkage disequilibrium for each pair of loci in all populations after sequential Bonferroni multiple-comparison correction based on 5500 permutations. Then, we used MICRO-CHECKER v.2.2.1 (Van Oosterhout et al. 2004), which allowed us to detect possible errors due to large allele dropout, identify scoring errors due to stuttering (i.e., failure to discriminate similarsized alleles in genotypes because of the presence of PCR artifacts), and estimate the frequencies of null alleles. The mean number of alleles per locus, number of private alleles $(P A)$ for the 11 studied loci in analyzed populations, mean polymorphic information content $(P I C)$, and observed $\left(H_{O}\right)$ and expected $\left(H_{E}\right)$ heterozygosity values were calculated with CERVUS 3.0.3. Deviations from Hardy-Weinberg equilibrium were tested with GENEPOP v.4.0.10 (Rousset 2008) using Fisher's exact tests. Markov chain analyses were applied to estimate significance $\left(10^{4}\right.$ dememorization steps, $10^{3}$ batches, $10^{4}$ iterations per batch). Significance levels were adjusted using the sequential method of Bonferroni for multiple comparisons in the same data set (Rice 1989). We used FSTAT to estimate the inbreeding coefficient $\left(F_{I S}\right)$ and allelic richness (alleles per locus; $A_{R}$ ) in the analyzed moose populations. Genetic differentiation between five moose populations was assessed by pairwise $F_{\mathrm{ST}}$ and $R_{\mathrm{ST}}$ values and statistically tested in ARLEQUIN v.3.11 using 10,000 permutations (Excoffier et al. 2006).

We used BOTTLENECK v.1.2.02 (Cornuet and Luikart 1996) to test for genetic signatures typical of a population that has undergone a genetic bottleneck. BOTTLENECK 
conducts tests for recent population bottlenecks (within the past $2 \mathrm{Ne}$ to $4 \mathrm{Ne}$ generations) that severely reduce effective population size $(\mathrm{Ne})$ and produce excess heterozygosity. Deviations from mutation-drift equilibrium were calculated under three different mutation models: stepwise mutation model (SMM), infinite allele's model (IAM), and two-phase model (TPM). The proportion of alleles attributed to SMM under the TPM was $90 \%$, with a variance of 12 (Garza and Williamson 2001). Significance was determined by the sign and Wilcoxon tests with 10,000 replications (Cornuet and Luikart 1996). We also checked the allele frequency distributions for mode shifts that discriminate recently bottlenecked from stable populations (Luikart et al. 1998). Second, the Garza-Williamson index $(M)$, which is a ratio of the number of alleles observed in a sample divided by the number of alleles expected under the observed size range (i.e., number of repeats) and can detect population bottlenecks from the far past (Garza and Williamson 2001), was also determined using ARLEQUIN.

Hierarchical analyses of molecular variance (AMOVA; Excoffier et al. 1992) was performed to study structuring within the microsatellites data, where the moose sampling sites were grouped as a single population (with both, $F_{\mathrm{ST}}$ and $R_{\mathrm{ST}}$ ) using ARLEQUIN (with 16,000 permutations) to test whether studied moose in eastern Poland form a single, panmictic population. A principal component analysis (PCA) was also carried out using microsatellites $F_{S T}$ and $R_{S T}$ data sets in GENALEX v.6.0 (Peakall and Smouse 2006). We used STRU CTURE v.2.3.4 (Pritchard et al. 2000; Falush et al. 2003) to investigate genetic structure of five moose populations and admixture levels. This analysis assumes that there are $K$ populations (where $K$ may be unknown). The admixture model and correlated allele frequencies were used in simulations, as suggested in Falush et al. (2003). The mean membership of each individual described the likelihood of that individual belonging to the respective clusters. To check if the results were consistent, we performed five independent runs checking the number of subpopulations (between $K=1$ and $K=5$ ) using 2,000,000 Markov Chain Monte Carlo (MCMC) iterations, following a burn-in period of 500,000 iterations. We then calculated the values for the $\log$ probabilities for each run and mean value for each $K$. We implemented the $\Delta K$ (Evanno et al. 2005) method to estimate the true value of $K$.

Finally, we used a Bayesian approach implemented in the software BAYESASS v.1.3 (Wilson and Rannala 2003) to estimate recent migration rates among the five analyzed moose populations in eastern Poland. The number of burn-in iterations was set to $1,000,000$ followed by $3,000,000$ iterations and a thinning of 2000. Initial input parameters of allele frequencies, migration, and inbreeding coefficient were set at 0.15 for each, respectively. We adjusted the delta values to 0.17 (allele frequency), 0.04 (migration), and 0.17 (inbreeding coefficient), so that acceptance rates for changes in these parameters would be between 40 and $60 \%$, as recommended by Faubet et al. (2007). We carried out four independent runs to confirm the consistency of results.

\section{Results and discussion}

Eight (21\%) of the 38 analyzed ungulate microsatellite primers gave no amplification in moose samples: BM861, INRA124, INRA189, INRA35, IOBT965, MM12, UMN2001, and UMN2404 (Table 5S1 and Table 6S2). All of them had previously been successfully amplified in cattle. The next ten loci-BM2830, CelJP15, Haut14, INRA003, NVHRT24, OarFCB20, RT9, RT23, RT24, and RT27—gave inconsistent amplification products with multiband profiles, and locus BMC1009 was monomorphic (Table 5S1). Eighteen of the 38 analyzed ungulate primers (47\%) amplified DNA, were polymorphic, and were characterized by 139 alleles in total in 23-202 tested moose samples. The mean number of alleles per locus was 10.27, ranging from 2 to 14 . These features demonstrate that the microsatellite loci used in this study are a good tool for studying genetic structure in $A$. alces.

The $S R Y$ primers gave a clear 333-bp peak in 85 males and no visible product in 117 females from five moose populations from eastern Poland. This means a 1:1.4 sex ratio in nonharvested moose from eastern Poland. This result is consistent with the sex ratio values obtained for the managed moose populations over the last 20 years in Estonia (from 1.2 to 1.9 females per male; Tõnisson 2005; Veeroja et al. 2010).

We discarded from our analysis the least polymorphic loci (BL42, BM888, BovirBP, CSM003, McM130, NVHRT01, OarFCB304, TGLA53); these loci had two to three alleles at maximum, the most common allele occurred at very high frequency, and the corresponding frequencies of rarer alleles were less than $1.5 \%$. In this way, we obtained two sets of 11 microsatellites on the basis of consistency of amplification and ease of scoring (Table 1). Significant linkage disequilibria $(p<0.009)$ were detected in 3 out of 55 pairwise comparisons between microsatellite loci in the Augustów Forest only (NVHRT21 and MAF70, BM4513 and MAF70, and MAF70 and Cer14) and for a single microsatellite pair of loci in Knyszyn Forest (BM1258 and MAF70) and Polesie National Park (OarFCB193 and MAF46) populations. This indicated that all studied loci were not linked. Analyses performed with MICRO-CHECKER v.2.2.1 (Van Oosterhout et al. 2004) showed that there were no scoring errors from large allele dropout and stuttering, and the frequency of null alleles was below $5 \%$ for 5 of 11 microsatellite loci (BM1258, MAF46, MAF70, NVHRT21, OarFCB193; Table 1). For the other six loci, the frequencies of null alleles were greater (BM1225, Cer14, MAF46, McM58, RT5, RT30; Table 1). 
Despite the fact, two out of 11 amplified loci (MAF46 and McM58) had higher frequencies of null alleles, we used all 11 microsatellite loci in our statistical analyses, as it did not change our results. For AMOVA, PCA, STRUCTURE, and BAYESASS, analyses were conducted using both 9 and 11 microsatellite loci. Genotyping of 231 moose samples at 11 microsatellite loci revealed 202 distinct multi-locus genotypes, e.g., individuals. In total, 113 alleles were found at 11 loci studied (from 7 to 14 per locus; Table 1). This is the highest numbers of alleles found in studied European moose populations so far (Table 2). In the Srokowo State Forest population, we identified the smallest number of alleles (63) and mean number of alleles per locus (5.73) at 11 loci among 17 individuals, while the largest number (96) of alleles and mean number of alleles per locus (8.73) was found in a group of 77 animals from the Biebrza Valley population. In the studied moose populations, the number of alleles ranged from 4 (locus MAF46 in the Srokowo State Forest) to 12 (locus McM58 in the Biebrza Valley). These results are generally consistent with reports for other moose populations (Schmidt et al. 2009; Kangas et al. 2013). For example, in the Finnish moose population, the number of alleles per locus ranged from 5 to 15 (Kangas et al. 2013) and in Alaska moose from 3 to 12 (Schmidt et al. 2009).

The polymorphic information content (PIC) values ranged from 0.656 (MAF70) to 0.857 (BM1225) over 11 loci amplified in 202 individuals, with a mean PIC value of 0.750 (Table 1). All the microsatellite loci we used had PIC value greater than 0.5 , indicating their usefulness for identifying individual moose sampled noninvasively. For the total sample, the observed heterozygosity $\left(H_{O}\right)$ ranged from 0.594 (locus McM58) to 0.770 (locus MAF46), averaging 0.769 across loci, while expected heterozygosity $\left(H_{E}\right)$ ranged from 0.688
(MAF70) to 0.874 (BM1225; Table 1), averaging 0.781 across loci. In particular, moose populations from eastern Poland the $H_{E}$ values ranged from 0.720 (Srokowo State Forest) to 0.786 (Augustów Forest; Table 2). Among all the moose populations studied so far, average $H_{E}$ across loci was highest in eastern Poland (0.781; Table 2): slightly higher than in the moose population from Finland (Kangas et al. 2013) and considerably higher than in other moose populations from Sweden (Charlier et al. 2008), Norway (Haanes et al. 2011), Alaska (Schmidt et al. 2009), and Canada (Wilson et al. 2003; Table 2). Although we examined about three times fewer individuals than in the Norwegian study and despite our samples represented a much smaller area, the $H_{E}$ value we obtained for eastern Poland was somewhat higher than for the population in Norway (0.630-0.650; Haanes et al. 2011). In moose populations from eastern Poland, we also identified one of the highest value of allelic richness $\left(A_{R}=6.363\right.$; Table 2$)$, being smaller that in Norway only (Haanes et al. 2011). Wilson et al. (2003) suggested that the moose is a species with reduced variation at microsatellite loci, but the values we obtained do not support that. The relatively high genetic variation in the study area seems to be due to the presence of individuals which possess mitochondrial DNA haplotypes belonging to the Biebrza, Fennoscandia, and Polesie phylogenetic branches of the Central Europe clade, along with moose that possessed mitochondrial DNA (mtDNA) haplotypes from the Ural mtDNA clade (Świsłocka et al. 2013). Immigrants typed as of eastern origin by mtDNA (e.g., Ural clade) represent from $19 \%$ of the moose population inhabiting the Biebrza marshes to $96 \%$ of the individuals in the Augustów Forest (Świsłocka et al. 2013). Indeed, when genetically different subpopulations merge, genetic variation can increase (Hartl and Clark 1997; Alleaume-Benharira et al. 2006).

Table 2 Comparison of genetic variability parameters using various sets of microsatellite loci in ten moose populations (Poland, Finland, Sweden, Norway, Canada, and Alaska)

\begin{tabular}{lccccccc}
\hline Species/population & $\mathrm{N}$ & No. of loci & No. of alleles & $A_{\mathrm{R}}$ & $F_{I S}$ & $H_{\mathrm{E}}$ & Reference \\
\hline BIE (Poland) & 77 & 11 & 96 & 6.633 & $0.090^{* * *}$ & 0.778 & This study \\
AUF (Poland) & 32 & 11 & 81 & 6.492 & 0.009 & 0.786 & This study \\
KNF (Poland) & 38 & 11 & 90 & 6.675 & $0.143^{* * *}$ & 0.755 & This study \\
PNP (Poland) & 38 & 11 & 83 & 6.403 & $0.173 * * *$ & 0.764 & This study \\
SRF (Poland) & 17 & 11 & 63 & 5.611 & 0.003 & 0.720 & This study \\
Eastern Poland & 202 & 11 & 113 & 6.363 & $0.112^{*}$ & 0.781 & This study \\
Finland & 130 & 8 & - & 4.700 & -0.004 & 0.740 & Kangas et al. 2013 \\
Sweden & 132 & 6 & 32 & - & $0.002 *$ & 0.640 & Charlier et al. 2008 \\
Norway & 585 & 15 & 112 & 7.400 & $0.022-0.078$ & $0.630-0.650$ & Haanes et al. 2011 \\
Canada & 259 & 5 & 28 & - & $-0.037-0.176$ & $0.378-0.610$ & Wilson et al. 2003 \\
Alaska & 141 & 8 & 46 & 3.785 & $-0.014-0.078$ & $0.483-0.616$ & Schmidt et al. 2009
\end{tabular}

$A_{R}$ allelic richness, $F_{I S}$ inbreeding coefficient with significance level, $H_{E}$ expected heterozygosity, BIE Biebrza valley, $A U F$ Augustów Forest, $K N F$ Knyszyn Forest, PNP Polesie National Park, SRF Srokowo State Forest, Eastern Poland five moose populations (BIE, AUF, KNF, PNP, and SRF)

$* p<0.05 ; * * * p<0.001$ 
We found 4 out of 11 loci in the 202 studied moose from eastern Poland to deviate significantly from Hardy-Weinberg equilibrium after sequential Bonferroni correction because of heterozygote deficit (Table 1). Deviation from HardyWeinberg equilibrium showed three loci (BM4513, MAF70, McM58) in the Biebrza moose population and McM58 locus in the Knyszyn Forest. The inbreeding coefficient value $\left(F_{\mathrm{IS}}\right)$ varied from 0.003 for moose from Srokowo State Forest to 0.173 for those from the Polesie National Park (Table 2). This parameter calculated for a set of 11 microsatellite loci was positive and significant $(p<0.001)$ in the Biebrza Valley, Knyszyn Forest, and Polesie National Park populations, and in general in eastern Poland $\left(F_{\mathrm{IS}}=0.112, p<0.05\right.$; Table 2$)$. When we used a data set of nine loci with low frequency of null alleles (without loci BM4513 and McM58), significant inbreeding coefficient was found in the Knyszyn Forest $\left(F_{\mathrm{IS}}=0.116, p=0.001\right)$ and Polesie National Park $\left(F_{\mathrm{IS}}=0.165, p=0.001\right)$ populations only. Thus, the presence of null alleles may increase the inbreeding coefficient values. A deficiency of heterozygotes based on deviation from Hardy-Weinberg equilibrium or on positive and significant $F_{I S}$ values can also result from the Wahlund effect, which usually comes from pooling samples from locally structured populations (Nielsen et al. 2003; Selkoe and Toonen 2006).

The BOTTLENECK software detected genetic drift in all moose populations in eastern Poland under the IAM model using either the sign test $(p \leq 0.029)$ or the Wilcoxon test $(p \leq$ 0.005 ; Table 3). The Knyszyn Forest population also showed signs of a recent bottleneck with the SMM by both the sign test $(p=0.035)$ and the Wilcoxon test $(p=0.009$; Table 3$)$. Moose populations from eastern Poland did not show any signs of bottleneck under the TPM mutation model. All 11 analyzed microsatellite loci showed a heterozygote excess under the IAM model, suggesting a recent bottleneck. Thus, despite recent demographic and spatial expansion, the studied moose population may still contain a signal of the population size reductions that occurred at the end of the nineteenth century and soon after the Second World War. However, the allele frequencies showed a normal L-shaped distribution in all populations, most probably due to admixture, as a high number of alleles per locus are not expected after a bottleneck. Interestingly, the Garza-Williamson index (the number of alleles divided by the allelic range) also suggested that bottleneck had occurred in all five moose populations from eastern Poland. This result is in full agreement with reports, according to which the species vanished from large parts of western and southern Central Europe from the Middle Ages to the nineteenth century and its number decreased in eastern Europe (Schmölcke and Zachos 2005). The G-W index ranged from 0.31 (Srokowo State Forest) to 0.42 (Biebrza Valley; Table 3). In general, values of $\mathrm{G}-\mathrm{W}$ index greater than 0.82 are representative of stable populations that have not suffered a known reduction in size, whereas values of $\mathrm{G}-\mathrm{W}$ index less than 0.70 suggest populations that have experienced a bottlenecking or founder event (Garza and Williamson 2001). Detecting a bottleneck can be difficult even in a population with well-documented reductions. A number of factors can affect and potentially blur the genetic signals of population decline: for example, the timing and duration of the bottleneck, immigration, and the level of prebottleneck genetic diversity (Garza and Williamson 2001; Williamson-Natesan 2005). Bottleneck tests did not detect population collapses in Scandinavian lynx (Lynx lynx; Spong and Hellborg 2002) and Amur tigers (Panthera tigris altaica; Henry et al. 2009), even though the demographic and genetic consequences of their low global population size put them at high risk of extinction (Peery et al. 2012). Noteworthy, Charlier et al. (2008) found evidence of a recent bottleneck in moose population from southern Sweden and suggested that it may be due to founder effects following recolonization of this part of Sweden at the beginning of the twentieth century or that it may be the result of intensive hunting pressure in past decades.

The genetic structure of bottlenecked populations may be broken down by high levels of migration and dispersal (Haanes et al. 2011). Despite recent bottlenecks, the Biebrza moose population, which originated from fewer than 20 animals, showed one of the highest reported levels of genetic variability at microsatellite loci. This most probably resulted from immigration and admixture of individuals from different sources. In a study of alpine ibex populations, Biebach and

Table 3 Results from the BOTTLENECK tests and Garza-Williamson index (G-W) for five studied moose population from eastern Poland

\begin{tabular}{|c|c|c|c|c|c|c|c|c|}
\hline \multirow{2}{*}{$\begin{array}{l}\text { Model } \\
\text { Population }\end{array}$} & \multicolumn{2}{|l|}{ IAM } & \multicolumn{2}{|l|}{ SMM } & \multicolumn{2}{|l|}{ TPM } & \multirow[t]{2}{*}{$\mathrm{G}-\mathrm{W}$ index } & \multirow[t]{2}{*}{$\mathrm{SD}$} \\
\hline & Sign test & Wilcoxon test & Sign test & Wilcoxon test & Sign test & Wilcoxon test & & \\
\hline BIE & $* * *$ & $* * *$ & ns & ns & ns & ns & 0.42 & 0.17 \\
\hline AUF & $* *$ & $* * *$ & ns & ns & ns & ns & 0.40 & 0.16 \\
\hline KNF & $* *$ & $* * *$ & $* *$ & $* * *$ & ns & $\mathrm{ns}$ & 0.40 & 0.13 \\
\hline PNP & $* *$ & $* * *$ & $\mathrm{~ns}$ & $\mathrm{~ns}$ & ns & $\mathrm{ns}$ & 0.38 & 0.20 \\
\hline SRF & $* *$ & $* * *$ & ns & ns & ns & ns & 0.31 & 0.12 \\
\hline
\end{tabular}

$n s$ nonsignificant deviation form used tests, $S D$ standard deviation for $\mathrm{G}-\mathrm{W}$ index

$* * p<0.01 ; * * * p<0.001$ 
Keller (2012) found that the degree of admixture in the recipient population has nearly three times the effect on the expected heterozygosity $\left(H_{E}\right)$ than the number of the founding group. Similarly, the effect of admixture on the standardized number of alleles was twice as strong. Thus, the high genetic variability we found in the bottlenecked moose populations reflects the strength of the effect of admixture. Indeed, Keller et al. (2001) showed that just a few immigrants entering a population can counteract the effects of genetic drift; populations that were admixed lost little genetic variation. As moose populations after the Second World War have continued to grow and expand in both the former Soviet Union and Poland, gene flow among them has been reestablished (Raczyński 2006).

Genetic differentiation $\left(F_{\mathrm{ST}}\right)$ between the studied moose populations at the studied microsatellite loci was low albeit statistically significant for all pairwise comparisons $(p<0.05)$, indicating that they may be of different origin. Values of $F_{\mathrm{ST}}$ ranged from 0.01 (Biebrza Valley vs Augusów Forest; Biebrza Valley vs Knyszyn Forest) to 0.04 (Augustów Forest vs Knyszyn Forest). $R_{\mathrm{ST}}$ showed low or moderate level of genetic differentiation between populations from eastern Poland and ranged from 0 (Biebrza Valley vs Srokowo State Forest; Knyszyn Forest vs Polesie National Park, $p>0.05$ ) to 0.07 (Augustów Forest vs Srokowo State Forest, $p<0.05$ ), and $60 \%$ of pairwise comparisons based on $R_{\mathrm{ST}}$ values did not differ significantly from zero ( $p>0.05)$. Significant $R_{\mathrm{ST}}$ values were found between Augustów Forest and all other populations from eastern Poland, indicating possible distinctness of this population. Our microsatellite results correspond to results obtained for mitochondrial DNA control region that revealed strong and significant genetic structuring among moose populations from eastern Poland (Świsłocka et al. 2013).

Geographical structuring among five moose populations in eastern Poland based on two data sets (11 and 9 loci with low
Table 4 Results of calculations of the most probable number of genetically distinct groups $(K)$ indicated by STRUCTURE for the two data sets (of all 11 loci and selected 9 microsatellite loci with low frequency of null alleles) and using the method of Evanno et al. (2005)

\begin{tabular}{|c|c|c|c|c|c|c|}
\hline \multicolumn{4}{|c|}{11 microsatellite loci } & \multicolumn{3}{|c|}{9 microsatellite loci } \\
\hline$K$ & $\mathrm{~L}(K)$ & SD & $\Delta K$ & $\mathrm{~L}(K)$ & SD & $\Delta K$ \\
\hline 1 & -7520.56 & 0.20 & & -6103.46 & 0.10 & \\
\hline 2 & -7533.46 & 12.87 & $15.62 \#$ & -6098.68 & 4.15 & $15.17 \#$ \\
\hline 3 & -7747.36 & 36.16 & 14.93 & -6156.84 & 9.16 & 14.23 \\
\hline 4 & -7421.52 & 23.78 & 11.58 & -6084.60 & 11.06 & 2.58 \\
\hline 5 & -7371.00 & 25.41 & & -6040.92 & 3.22 & \\
\hline
\end{tabular}

STRUCTURE returned the greatest log probabilities for $K=5$ for both data sets. However, with $K=3$, the rate of increase in log probability notably declined. The most probable number of groups for moose in eastern Poland according to the method of Evanno et al. (2005) is $K=2$ (denoted as \#)

$K$ number of groups, $L(K)$ mean value of the posterior probability of $K$ calculated in STRUCTURE for different $K$ values ( $K$ from 1 to 5), $\Delta K$ second-order rate of change of the log probability of data between successive $K$ values (Evanno et al. 2005)

frequency of null alleles) was supported by AMOVA results where all sampling sites were treated as a single group $\left(F_{\mathrm{ST}}=\right.$ $0.02 ; p<0.001$ in both cases). This means that moose in eastern Poland do not constitute a single panmictic unit. The genetic structuring among analyzed moose populations was further revealed by PCA analyses, and results were the same for 11 and 9 loci studied. The first and second axes of the PCA (PC1 and PC2) performed on the $F_{\mathrm{ST}}$ data explained 50.16 and $35.02 \%$ of the total microsatellites variability, respectively. The analysis showed that moose from the Biebrza Valley, Augustów Forest, and Knyszyn Forest (with respect to both PC1 and PC2) populations constitute one group, while the other two groups are

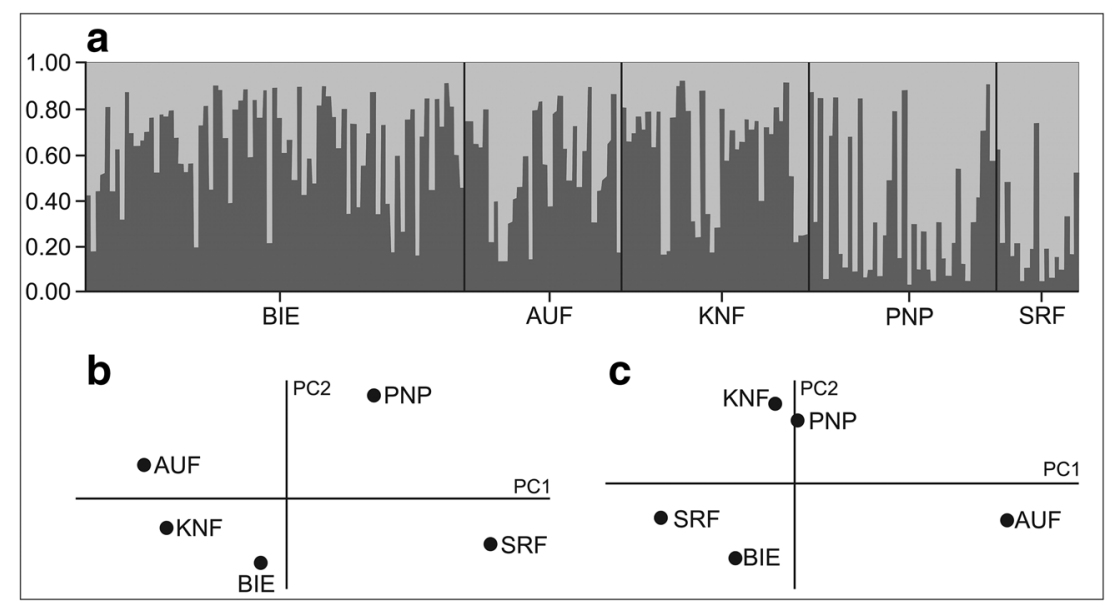

Fig. 2 Population structure of moose in eastern Poland according to 11 microsatellite markers. a Bar plots of the STRUCTURE results with $K=2$. b Principal component analysis (PCA) performed on pairwise $F_{\mathrm{ST}}$ values of the studied moose populations in eastern Poland. The first and second axes of the PCA explained 50.16 and $35.02 \%$ of the total microsatellites variability, respectively. c Principal component analysis (PCA) performed on pairwise $R_{\mathrm{ST}}$ values of the studied moose populations in eastern Poland. The first and second axes of the PCA explained 71.59 and $23.34 \%$ of the total microsatellite variability, respectively 
formed by single populations: the Polesie National Park (with respect to both PC1 and PC2) and Srokowo State Forest (with respect to PC1; Fig. 2b). Based on the matrix of $R_{\mathrm{ST}}$, the first and second axes of the PCA explained 71.59 and $23.34 \%$ of the total variability, respectively. The analysis revealed that, with respect to both $\mathrm{PC} 1$ and $\mathrm{PC} 2$, we have three groups of moose populations in eastern Poland: (1) Biebrza Valley and Srokowo State Forest, (2) Knyszyn Forest and Polesie National Park, and (3) Augustów Forest (Fig. 2c). The genetic similarity of the Biebrza Valley and the Srokowo State Forest moose populations revealed by $R_{\mathrm{ST}}$ coincides with the presence of the haplotype H10 in the Srokowo State Forest that grouped with the H1 haplotype from the Biebrza branch (Świsłocka et al. 2013). Moose from these populations could have belonged to a large autochthonous group that was present in Poland before a severe bottleneck occurred at the beginning of the nineteenth century (Brincken 1826). The remaining two moose populations in Poland most probably have an eastern origin, as suggested by the predominance of individuals possessing mtDNA haplotypes from the Ural clade (Świsłocka et al. 2013).

Based on AMOVA results and the clustering analysis performed in STRUCTURE using the Evanno et al. (2005) method, we concluded that $K=2$ is the most probable number of clusters in our study (Table 4, Fig. 2a). Again, similar results were obtained from the analysis of 11 and 9 loci. The first cluster consisted of moose populations from the Biebrza Valley, and Augustów and Knyszyn Forests, likewise in PCA analysis using the $F_{\mathrm{ST}}$ matrix. The membership coefficients were 0.543 (Augustów Forest), 0.604 (Knyszyn Forest), and 0.634 (Biebrza Valley). The second cluster included individuals from the other two populations. The membership coefficient in the second inferred cluster was 0.634 (Polesie National Park) and 0.748 (Srokowo State Forest; Fig. 2a). This indicates considerable exchange of individuals between the identified genetic groups. Descendants of the autochthonous Biebrza population, which survived the Second World War, dispersed mostly to neighboring Augustów and Knyszyn Forests. A significant contribution into developing the Srokowo State Forest and Polesie National Park populations after the Second World War was also from the east. We found high rates of self-recruitment in the Biebrza moose population and high recent migration rates from this population into the other four recipient populations using BAYESASS (Fig. 1). Our results indicated that at present, $98 \%$ of the moose sampled in the Biebrza Valley originated from the same population and as few as $2 \%$ of the individuals came from the other four populations. For the other moose populations studied, the proportion of nonmigrants ranged from $68.4 \%$ (Srokowo State Forest) to $78.8 \%$ (Polesie National Park; Fig. 1), being in accordance with STRUCTURE analysis. The immigration from the Biebrza population into the other populations from eastern Poland was considerable and varied from 19.1 (Polesie National Park) to 28.1 \% (Augustów Forest; Fig. 1). This shows that the Biebrza Valley is currently a "source population" for the other populations and its future management may have very important consequences on the other moose populations in the region under study and whole moose population in Poland, as over $70 \%$ of census size is present in northeastern Poland. It should be noted that BAYESASS has however problems with the convergence of the Markov Chain Monte Carlo, which tends to get trapped near the bounds of the prior distribution, and the quality of the inference may be low under weak population structure measured by small $F_{\mathrm{ST}}$ values (Meirmans 2014).

\section{Conclusions}

Our results using 11 microsatellite loci from studies of various ungulate species confirm the usefulness of these markers for moose population genetic studies, showing good detection, relatively high polymorphism, and an acceptable level of null alleles. Together with $S R Y$ amplification for sex identification, this set of loci provides a useful tool for population genetics approaches that employ noninvasive sampling. We found both recent bottleneck and high genetic variability in studied moose populations in eastern Poland, a combination most probably attributable to recent admixture after spatial and demographic expansion. The Biebrza population is characterized by limited immigration level; however, it is currently a "source population" for the other populations in eastern Poland. Like the majority of moose populations in Europe, the nonharvested populations in eastern Poland show a female-biased sex ratio.

Acknowledgments This work was funded by the Polish Ministry of Science and Higher Education (grant no. N N304 024134 to M. Ratkiewicz), for the Biebrza National Park population, and by the National Fund for Environmental Protection and Water Management for the other populations (project no. 326/09/Wn50/NE-PR-IX/D). Magdalena Świsłocka is a beneficiary of the "Scholarships for PhD students of Podlaskie Province" project, which is cofinanced by the European Social Fund, the Polish Government and Podlaskie Province. Michael Jacobs line-edited the paper for submission. Figures 1 and 2 were drawn by P. Rode.

Compliance with ethical standards Authors declare no conflicts of interests (financial or nonfinancial). Conceived and designed the experiments: MŚ, MR. Performed the experiments: MŚ, MC, MR, ND. Analyzed the data MŚ, MR. Contributed reagents/materials/analysis tools: MR, MŚ. Contributed to the writing of the manuscript: MŚ, MR. Informed consent: all analyses were performed with accepted principles of ethical and professional conduct, only noninvasively collected samples were used and analyzed in the appropriate way. The research did not affect any animals and/or wildlife.

Open Access This article is distributed under the terms of the Creative Commons Attribution License which permits any use, distribution, and reproduction in any medium, provided the original author(s) and the source are credited. 


\section{References}

Alleaume-Benharira M, Pen IR, Ronce O (2006) Geographical patterns of adaptation within a species' range: interactions between drift and gene flow. J Evol Biol 19:203-2015. doi:10.1111/j.1420-9101. 2005.00976.x

Arandjelovic M, Head J, Rabanal LI, Schubert G, Mettke E, Boesch C, Robbins MM, Vigilant L (2011) Non-invasive genetic monitoring of wild central chimpanzees. PLoS ONE 6(3):e14761. doi:10.1371/ journal.pone. 0014761

Barendse W, Armitage SM, Kossarek LM, Shalom A, Kirkpatrick BW, Ryan AM, Clayton D, Li L, Neibergs HL, Zhang N, Grosse WM, Weiss J, Creighton P, McCarthy F, Ron M, Teale AJ, Fries R, McGraw RA, Moore SS, Georges M, Soller M, Womack JE, Hetzel DJS (1994) A genetic linkage map of the bovine genome. Nat Genet 6:227-235. doi:10.1038/ng0394-227

Biebach I, Keller LF (2012) Genetic variation depends more on admixture than number of founders in reintroduced Alpine ibex populations. Biol Conserv 147:197-203. doi:10.1016/j.biocon.2011.12. 034

Bishop MD, Kappes SM, Keele JW, Stone RT, Sunden SLF, Hawkins GA, Toldo SS, Fries R, Grosz MD, Yoo J, Beattie CW (1994) A genetic linkage map for cattle. Genetics 136:619-639

Bouzat JL (2010) Conservation genetics of population bottlenecks: the role of chance, selection, and history. Conserv Genet 11:463-478. doi:10.1007/s10592-010-0049-0

Brincken J (1826) Memoire descriptif sur la foret imperiale de Białowieża en Lithuanie. N. Glückserg, Warsaw [In French]

Buchanan FC, Crawford AM (1992) Ovine dinucleotide repeat polymorphism at the MAF70 locus. Anim Genet 23:185. doi:10.1111/j. 1365-2052.1992.tb00043.x

Buchanan FC, Crawford AM (1993) Ovine microsatellites at the OarFCB11, OarFCB128, OarFCB193, OarFCB266 and OarFCB304 loci. Anim Genet 23:145. doi:10.1111/j.1365-2052. 1993.tb00269.x

Buchanan FC, Galloway SM, Crawford AM (1994) Ovine microsatellites at the OarFCB5, OarFCB19, OarFCB20, OarFCB48, OarFCB129 and OarFCB226 loci. Anim Genet 25:60. doi:10.1111/j.1365-2052. 1994.tb00461.x

Charlier J, Laikre L, Ryman N (2008) Genetic structure and evidence of a local bottleneck in moose in Sweden. J Wildl Manag 72:411-415. doi: $10.2193 / 2007-122$

Cornuet JM, Luikart G (1996) Description and power analysis of two tests for detecting recent population bottlenecks from allele frequency data. Genetics 144:2001-2014

Czernik M, Taberlet P, Świsłocka M, Czajkowska M, Duda N, Ratkiewicz M (2013) Fast and efficient DNA-based method for winter diet analysis from stools of three cervids: moose, red deer, and roe deer. Acta Theriol 58:379-386. doi:10.1007/s13364-0130146-9

DeWoody JA, Honeycutt RL, Skow LC (1995) Microsatellite markers in white-tailed deer. J Hered 86:317-319

Dzięciołowski R, Pielowski P (1993) Alces. Anton-5 Sp. z o.o., Warsaw, pp 1-208 [In Polish]

Evanno G, Regnaut S, Goudet J (2005) Detecting the number of clusters of individuals using the software STRUCTURE: a simulation study. Mol Ecol 14:2611-2620. doi:10.1111/j.1365-294X.2005.02553.x

Excoffier L, Smouse PE, Quattro JM (1992) Analysis of molecular variance inferred from metric distances among DNA haplotypes: application to human mitochondrial DNA restriction data. Genetics 131: 479-491

Excoffier L, Laval G, Schneider S (2006) ARLEQUIN ver 3.1: an integrated software package for population genetics date analysis. Genetics and Molecular Genetics Population Lab, Institute of Zoology. University of Geneva, Switzerland
Falush D, Stephens M, Pritchard JK (2003) Inference of population structure using multilocus genotype data: linked loci and correlated allele frequencies. Genetics 164:1567-1587

Faubet P, Waples RS, Gaggiotti OE (2007) Evaluating the performance of a multilocus Bayesian method for the estimation of migration rates. Mol Ecol 16:1149-1166. doi:10.1111/j.1365-294X.2007.03218.x

Garza JC, Williamson EG (2001) Detection of reduction in population size using data from microsatellite loci. Mol Ecol 10:305-318. doi: 10.1046/j.1365-294X.2001.01190.x

Gębczyńska Z, Raczyński J (2004) Moose in the Biebrza River valley. In: The situation of moose populations in Poland. Biebrza National Park Press, Osowiec, 5-19 [In Polish]

Goudet J (1995) FSTAT (version 2.9.3): a computer program to calculate F-statistics. J Hered 86:485-486

Graham RT, Jain TB, Kingery JL (2010) Ameliorating conflicts among deer, elk, cattle and/or other ungulates and other forest uses: a synthesis. Forestry 83:245-255. doi:10.1093/forestry/cpq003

Grueber CE, Wallis GP, Jamieson IG (2008) Heterozygosity-fitness correlations and their relevance to studies on inbreeding depression in threatened species. Mol Ecol 17:3978-3984. doi:10.1111/j.1365294X.2008.03910.x

Haanes H, Røed KH, Solberg EJ, Herfindal I, Sæther BE (2011) Genetic discontinuities in a continuously distributed and highly mobile ungulate, the Norwegian moose. Conserv Genet 12:1131-1143. doi: 10.1007/s10592-011-0214-0

Hartl DL, Clark AG (1997) Principles of population genetics, 3rd edn. Sinauer, Sunderland

Hediger R, Ansari HA, Stranzinger G (1991) Chromosome banding and gene localizations support extensive conservation of chromosome structure between cattle and sheep. Cytogenet Cell Genet 57:127134. doi: $10.1159 / 000133131$

Hedrick PW, Fredrickson R (2010) Genetic rescue guidelines with examples from Mexican wolves and Florida panthers. Conserv Genet 11: 615-626. doi:10.1007/s10592-009-9999-5

Henry P, Miquelle D, Sugimoto T, McCullough DR, Caccone A, Russello MA (2009) In situ population structure and ex situ representation of the endangered Amur tiger. Mol Ecol 18:3173-3184. doi:10.1111/j. 1365-294X.2009.04266.X

Hulme DJ, Silk JP, Redwin JM, Barendse W, Beh KJ (1994) Ten polymorphic ovine microsatellites. Anim Genet 25:434-435. doi:10. 1111/j.1365-2052.1994.tb00543.x

Hundertmark KJ, Shields GF, Udina IG, Bowyer RT, Danilkin AA, Schwartz CC (2002) Mitochondrial phylogeography of moose (Alces alces): late Pleistocene divergence and population expansion. Mol Phylogenet Evol 22:375-387. doi:10.1006/mpev.2001.1058

Kalinowski ST, Taper ML, Marshall TC (2007) Revising how the computer program CERVUS accommodates genotyping errors increases success in paternity assignment. Mol Ecol 16:1099-1106. doi:10. 1111/j.1365-294X.2007.03089.x

Kangas VM, Kvist L, Laaksonen S, Nygrén T, Aspi J (2013) Present genetic structure revealed by microsatellites reflects recent history of the Finnish moose (Alces alces). Eur J Wildl Res 59:613-627. doi: 10.1007/s10344-013-0712-0

Kappes SM, Keele JW, Stone RT, McGraw RA, Sonstegard TS, Smith TP, Lopez-Corrales NL, Beattie CW (1997) A second-generation linkage map of the bovine genome. Genome Res 7:235-249. doi: $10.1101 /$ gr.7.3.235

Keller LF, Jeffery KJ, Arcese P, Beaumont MA, Hochachka WM, Smith JNM, Bruford MW (2001) Immigration and the ephemerality of a natural population bottleneck: evidence from molecular markers. Proc R Soc Lond B 268(1474):1387-1394. doi:10.1098/rspb. 2001.1607

Kohler K, Barekati Z, Radpour R, Zhong XY (2011) Cell-free DNA in the circulation as a potential cancer biomarker. Anticancer Res 31: 2623-2628 
Liu WS, Mariani P, Beattie CW, Alexander LJ, de León FAP (2002) A radiation hybrid map for the bovine $\mathrm{Y}$ chromosome. Mamm Genome 13:320-326. doi:10.1007/s00335-001-2133-8

Liu WS, Beattie CW, de León FAP (2003) Bovine Y chromosome microsatellite polymorphisms. Cytogenet Genome Res 102:53-58. doi: $10.1159 / 000075725$

Luikart G, Allendorf FW, Cornuet JM, Sherwin WB (1998) Distortion of allele frequency distributions provides a test for recent population bottlenecks. J Hered 89:238-247

Meirmans PG (2014) Nonconvergence in Bayesian estimation of migration rates. Mol Ecol Resour 14:726-733. doi:10.1111/1755-0998. 12216

Moore SS, Barendse W, Berger KT, Armitage SM, Hetzel DJS (1992) Bovine and ovine DNA microsatellites from the EMBL and GENBANK database. Anim Genet 23:463-467. doi:10.1111/j. 1365-2052.1992.tb02168.x

Moore SS, Byrne K, Berger KT, Barendse W, McCarthy F, Womack JE, Hetzel DJS (1994) Characterization of 65 bovine microsatellites. Mamm Genome 5:84-90

Mysterud A, Langvatn R, Yoccoz NG, Stenseth NC (2002) Large-scale habitat variability, delayed density effects and red deer populations in Norway. J Anim Ecol 71:569-580. doi:10.1046/j.1365-2656. 2002.00622.x

Niedziałkowska M, Hundertmark KJ, Jędrzejewska B, Niedziałkowski K, Sidorovich VE, Górny M, Veeroja R, Solberg EJ, Laaksonen S, Sand H, Solovyev VA, Shkvyria M, Tiainen J, Okhlopkov IM, Juškaitis R, Done G, Borodulin VA, Tulandin EA, Jędrzejewski W (2014) Spatial structure in European moose (Alces alces): genetic data reveal a complex population history. J Biogeogr. doi:10.1111/jbi.12362

Nielsen EE, Hansen MM, Ruzzante DE, Meldrup D, Grønkjær P (2003) Evidence of a hybrid-zone in Atlantic cod (Gadus morhua) in the Baltic and the Danish Belt Sea revealed by individual admixture analysis. Mol Ecol 12:1497-1508. doi:10.1046/j.1365-294X.2003. 01819.x

Peakall R, Smouse PE (2006) GENALEX 6: genetic analysis in Excel. Population genetic software for teaching and research. Mol Ecol Notes 6:288-295. doi:10.1111/j.1471-8286.2005.01155.x

Peery MZ, Kirby R, Reid BN, Stoelting R, Doucet-Bëer E, Robinson S, Vásquez-Carrillo C, Pauli JN, Palsbøll PJ (2012) Reliability of genetic bottleneck tests for detecting recent population declines. Mol Ecol 21:3403-3418. doi:10.1111/j.1365-294X.2012.05635.x

Pemberton JM, Slate J, Bancroft DR, Barrett JA (1995) Nonamplifying alleles at microsatellite loci: a caution for parentage and population studies. Mol Ecol 4:249-252. doi:10.1111/j.1365-294X.1995. tb00214.x

Pritchard JK, Stephens M, Donnelly P (2000) Inference of population structure using multilocus genotype data. Genetics 155:945-959

Queiros J, Vicente J, Boadella M, Gortázar C, Alves PC (2014) The impact of management practices and past demographic history on the genetic diversity of red deer (Cervus elaphus): an assessment of population and individual fitness. Biol J Linn Soc 111:209-223. doi: 10.1111/bij.12183

Raczyński J (2006) Moose in Poland: status and prospects. In: Is there a place for moose? Uroczysko Supraśl. 25-38 [In Polish with English summary]

Rice WR (1989) Analyzing tables of statistical tests. Evolution 43:223225

Røed KH, Midthjell L (1998) Microsatellites in reindeer, Rangifer tarandus, and their use in other cervids. Mol Ecol 7:1773-1776. doi:10.1046/j.1365-294x.1998.00514.x

Rousset F (2008) GENEPOP'007: a complete reimplementation of the GENEPOP software for Windows and Linux. Mol Ecol Resour 8: 103-106. doi:10.1111/j.1471-8286.2007.01931.x

Schmidt JI, Hundertmark KJ, Bowyer RT, McCracken KG (2009) Population structure and genetic diversity of moose in Alaska. J Hered 100:170-180. doi:10.1093/jhered/esn076
Schmölcke U, Zachos FE (2005) Holocene distribution and extinction of the moose (Alces alces, Cervidae) in Central Europe. Mamm Biol 70:329-344. doi:10.1016/j.mambio.2005.08.001

Selkoe KA, Toonen RJ (2006) Microsatellites for ecologists: a practical guide to using and evaluating microsatellite markers. Ecol Lett 9: 615-629. doi:10.1111/j.1461-0248.2006.00889.x

Spong G, Hellborg L (2002) A near-extinction event in lynx: do microsatellite data tell the tale? Conserv Ecol 6(1):15. Available at: http:// www.consecol.org/vol6/iss 1/art15

Steffen P, Eggen A, Stranzinger G, Fries R, Dietz AB, Womack JE (1993) Isolation and mapping of polymorphic microsatellites in cattle. Anim Genet 24:121-124. doi:10.1111/j.1365-2052.1993.tb00252.x

Swarbrick PA, Dietz AB, Womack JE, Crawford AM (1992) Ovine and bovine dinucleotide repeat polymorphism at the MAF46 locus. Anim Genet 23:182. doi:10.1111/j.1365-2052.1992.tb00040.x

Świsłocka M, Ratkiewicz M, Borkowska A, Komenda E, Raczyński J (2008) Mitochondrial DNA diversity in moose, Alces alces from Northeastern Poland: evidence for admixture in bottlenecked relic population in the Biebrza valley. Ann Zool Fenn 45:360-365. doi: 10.5735/086.045.0419

Świsłocka M, Czajkowska M, Duda N, Danyłow J, Owadowska-Cornil E, Ratkiewicz M (2013) Complex patterns of population genetic structure of moose, Alces alces, after recent spatial expansion in Poland revealed by sex-linked markers. Acta Theriol 58:367-378. doi:10.1007/s13364-013-0148-7

Taberlet P, Luikart G (1999) Non-invasive genetic sampling and individual identification. Biol J Linn Soc 68(1-2):41-55. doi:10.1111/j. 1095-8312.1999.tb01157.x

Talbot J, Haigh J, Plante Y (1996) A parentage evaluation test in North American Elk (Wapiti) using microsatellites of ovine and bovine origin. Anim Genet 27:117-119. doi:10.1111/j.1365-2052.1996. tb00480.x

Thieven U, Harlizius B, Simon D (1995) Dinucleotide repeat polymorphism at the bovine HAUT1 and HAUT14 loci. Anim Genet 26: 123. doi:10.1111/j.1365-2052.1995.tb02646.x

Tõnisson J (2005) Management of Estonian moose population in 2004. Project report to Estonian ministry of environment. Centre of Forest Protection and Silviculture, Tartu [In Estonian]

Vaiman D, Osta R, Mercier D, Grohs C, Leveziel H (1992) Characterization of five new bovine dinucleotide repeats. Anim Genet 23:537-541. doi:10.1111/j.1365-2052.1992.tb00175.x

Vaiman D, Mercier D, Moazami-Goudarzi K, Eggen A, Ciampolini R, Lépingle A, Velmala R, Kaukinen J, Varvio SL, Martin P, Levéziel H, Guérin G (1994) A set of 99 cattle microsatellites: characterization, synteny mapping, and polymorphism. Mamm Genome 5:288-297

Van Oosterhout C, Hutchinson WF, Wills DPM, Shipley P (2004) MICRO-CHECKER: software for identifying and correcting genotyping errors in microsatellite data. Mol Ecol Notes 4:535538. doi:10.1111/j.1471-8286.2004.00684.x

Veeroja R, Kirk A, Tilgar V, Säde S, Kreitsberg M, Tõnisson J (2010) Conception date affects litter type and foetal sex ratio in female moose in Estonia. J Anim Ecol 79:169-175. doi:10.1111/j.13652656.2009.01599.x

Williamson-Natesan EG (2005) Comparison of methods for detecting bottlenecks from microsatellite loci. Conserv Genet 6:551-562. doi:10.1007/s10592-005-9009-5

Wilson GA, Rannala B (2003) Bayesian inference of recent migration rates using multilocus genotypes. Genetics 163:1177-1191

Wilson GA, Strobeck C, Wu L, Coffin JW (1997) Characterization of microsatellite loci in caribou Rangifer tarandus, and their use in other artiodactyls. Mol Ecol 6:697-699. doi:10.1046/j.1365-294X. 1997.00237.x

Wilson PJ, Grewal S, Rodgers A, Rempel R, Saquet J, Hristienko H, Burrows F, Peterson R, White BN (2003) Genetic variation and population structure of moose (Alces alces) at neutral and functional DNA loci. Can J Zool 81:670-683. doi:10.1139/z03-030 